\title{
Interpersonal Communications In Preventing Child Sexual Abuse
}

\author{
Dewi Kurniawati \\ Department of Communication Science \\ Faculty of Social and Politic Sciences, Sumatera Utara University, Medan, Indonesia \\ kurniawatidewi65@gmail.com
}

\begin{abstract}
Providing sexual education or reproduction health education for children as early as possible by parents and school is necessary to prevent children receiving misleading informations from their peers, internet and other media. Parents themselves sometimes find it difficult to have conversations regarding sexuality with their children,they consider it as a taboo object when their children asking them questions regarding these matter. Parents tend to be defensive and ask their children to never bring up the subject in their conversations. Interpersonal communications between parents and their children has important role in effort to anticipate sexual abuse in children. Interpersonal communication between parents and children play an important role to anticipate the sexual abuse against children. Parents can communicate the positive and negative effects of media especially television which has increasing number of sexuality contents along recent decades. Parents can communicate the importance of keeping themselves in anticipation of sexual abuse
\end{abstract}

Keyword: interpersonal communications, sexual abuse.

\section{INTRODUCTION}

Recently, we were surprised by the news of rape and murder against Yuyun, a girl aged 14 who was raped in turns by 14 teenage boys in Bengkulu. What made it tragic is, after committing such heinous things, they killed her and dumped her body alongside a ravine near the Victim's house.

Other than that, there are many more cases in the news media that contained cases of sexual abuse against children in our country. It is like the children in our country have become that immoral so they can do such a nasty things. So it is a proper that the institutions and parties concerned to think and forming such a team to find a solution for this problem.

Interpersonal communication between parents and children play an important role in giving a positive influence of child behavior. Researcher hope this article can provide a good influence for the parties concerned to solve this problem.

\section{Sexual Violence Against Children}

Based on data from the National Commission for Child Protection, in 2009 the cases of child abuse has reached 1998 cases, about 65 percent of them, are cases of sexual abuse(http://www.antaranews.com).Where previously, in 2008 the cases of sexual abuse of children has increased 30 percent to 1,555 cases from 1,194 cases in 2007. In other words, every single day there are 4.2.cases of thismatter (http://www.tempointeraktif.com). Data of 2008 that obtained from LBH Jakarta shows there are increase in cases of violent or sexual crimes against children as much as twofold of 35 cases from the previous year which reached 16 cases. The sadden thing is, for rape and sexual immorality types of cases, the suspect was childrenagedamong10 
to 17

years

(http://megapolitan.infogue.com). From the clients who come to PULIH there were 7 cases of child sexual abuse in September 2009 to June 2010. The reported data are less than the actual data exists. This is because not all children who have been sexually abused would report the incident that happened to the parents and the authorities.

The important thing to do is to provide sexual education or reproductive health education for children as early as possible, It should be formed by parents and school so that children do not get wrong information from friends, internet, and other media. Parents sometimes have difficulties to talk to their children about sexuality, they assume it is still taboo, when a child asks parents about sexuality, parents would scold the child and instruct children not to talk in front of the parents. As a result, children become afraid to ask questions when a child asks to their parents, where it is such a good time for parents to talk about sexuality. Spurred on high curiosity, the child will seek the answers of the question to another source of information that is not necessarily appropriate, such as friends or the internet.

Some steps that parents should do when explaining about sexuality is: Listen carefully to every child's question. The sitting position should be parallel, look into children's eyes so that children feel themselves noticed. Do not avoid or ignore your child's questions. Answer as soon as possible all of children's question . Delaying the answer means waste a golden opportunity to talk about sex with children. But if the parents are not ready to answer, say it honestly to children that their parents will find out the answer first. Give answers only the questions of children, do not need to be widened to other topics. When parents are confused by child's questions, we should ask the child about the mean of the question. Such as when a child asks about sex, it does not mean the child has to understand about sex as it is thought by adults.

Children do not understand abstract concepts. They will question the terms they hear or see on television, the internet, etc. Give a brief explanation as a simple and easy as possible with understandable language for children such as when a child asks about what's nipples, answer it as nipples is where the baby have to suck for milk from the mother's breast. When a child asks why "his/her genitals" is different from "mine". Please answer using the correct terms such as male genitals is different from the female genitalia. Male genitalia called penis while female genitalia called a vagina. Not by terms such as "bird", "wallet", etc.

Provide answers with reasonable and normal voice and facial expressions. Do not feel pressured when answering such questions. Responds with shocked facial expression, face flushed, and wide-eyes and will create an impression on the child that the questions wrong and not something that is reasonable. For example, when children ask about condoms. Answer it calmly that it is medical equipment that is used fathers or male adult to prevent pregnancy.

\section{Interpersonal Communication}

Interpersonal communication is the process of exchanging information between a person with at least one other or usually between two people who could be directly known the feedback (Muhammad, 2005: 159). Mulyana (2000: 73) states that "interpersonal communication is 
communication that only two people, such as husband and wife, two colleagues, two close friends, teachers, students and so on".

According to Effendy (2003: 60) as compared to other forms of communication, interpersonal communication is considered the most powerful to change attitudes, beliefs, opinions and behaviors of communicant. The reason is because interpersonal communication is generally done face to face, and it resulting in personal contact. When the message is delivered, it gave immediate feedback. It means, the communicator can see the response of communicant from the message that was brought up at that time, for example through facial expressions, can be concluded that interpersonal communication is the process of delivering information, thoughts and attitudes of particular between two or more people that there are a changing message between both a communicant and communicators with the object to achieve mutual understanding about the issues discussed that are expected to be a behavioral changes. According to Everett M. Rogers (in Cangara, 2012: 22) communication is the process where an idea is transferred from the source to one or more recipients with a view to changing their behavior.

It is also supported by the opinion of Effendy (2003: 52), which states that one purpose of communication is to change the behavior. According Cangara (2012: 36) by its nature, interpersonal communication can be divided into two type, it is dyadic communication and small group communication. Dyadic communication is the process of communication that takes place between two people in face to face situations. Dyadic communication can be done in three forms, it is conversation, dialogue and interviews. The conversation took place in a friendly and informal atmosphere. Dialogue takes place in a situation that is more intimate, deeper and more personal, while the interview is more serious, while the dominant part in the position of asking and others in a position to answer. Small group communication is the process of communication that takes place between three or more people face to face, where the members interact with each other. Small group communication is classified as the type of interpersonal communication because:

1. The members involved in the face to face communication process.

2. Discussion performed one by one in which all participants can speak in the same position, in other words, no single speaker who dominate the situation.

3. Presenter and recipient are difficult to identified. In situations like this, all members can serve as a presenter as well as a recipient

Therefore the effect can be vary. This communication process is normally found in study groups and discussion groups. Theres no limits to determines how much member of a small group. Usually between 2-3 people, and some even develop up to 20-30 people, but no more than 50 people (Cangara, 2012: 36).

Associated with the research, so one of communication theory that is interpersonal communication is a fundamental theory that used in this study. This is because the main reason of the research is to see how the process of communication between parents and their children. Therefore, the theory that most appropriate to used is interpersonal communication because it involves 
communication between two people-face to face which is the definition of the interpersonal communication.

\section{Verbal Communication}

Verbal

communication

is

communication that use words both spoken or written. This type of communication is the most widely used in human relationships. Through words, they express their feelings, emotions, thoughts, ideas or intentions, convey facts, data and information also to explain, exchanging feelings and thoughts, arguing and fighting. In this verbal communication, the language plays a very important role (Hardjana, 2003: 22).

Symbols or verbal messages are all kinds of symbols that use a word or almost all speech stimulation that we consciously included into the category of intentional verbal message, that is the efforts that made consciously to communicate to others verbally. The Verbal code system is called language. Language can be defined as a set of symbols, with rules for combining these symbols, which are used and understood by a community. Verbal language is the primary means to unify the mind, feeling and our intentions. Verbal language using the words that present various aspects of our individual reality.

Consequently, words is our abstracts reality that cannot cause a reaction totality of objects or concepts that represented by the words (Mulyana, 2007: 260).

According to Lary L. Barker (in Mulyana, 2007: 266) language functions, there are three: first, Labeling function naming or referring to the attempt to identify the object, action or person by name so it can be referenced in communication, interaction and transmission of information.
The second function of the interaction, which emphasizes the ideas and emotions that can invite sympathy and understanding or anger and confusion. Through language, information can be passed on to others either directly or indirectly (through the mass media, for example) function is called transmission function. The speciality of the language as a time-across transmission information, by linking the past, present and future, enabling the continuity of our culture and tradition. Without language we could not exchange information, we cannot bring all of the objects and places of reconciliation in our communications. Barker added that for successful communication, at least the language must fulfill three functions: to know the world around us because through the language we learn about what is around us, relate to others, that is related to the function of communication, and to create coherence in our lives where this function allow us to live more organized, mutual understanding about ourselves, our beliefs and our goals (Mulyana, 2007: 266).

\section{Television As Media Communications}

Television technology grew rapidly in the late 1940s. Earlier, the television technology development had been halted due to the Second World War. The television reporter, who was previously general radio reporter doing an intensive reporting that urged the role of radio. But the news still important for radio, although the character were changed. Because of its eyeattractiveness, most of the television broadcast is a non-news program. But the role of television as the news media continues to grow. Many television broadcast that is interesting because it is actual, straightforward and exhaustive in covering some news. 
The popularity of television continueslyshift the position of radio. Both are in the family room, so the two never turned on the same time. Only one thing is turned on, and it usually is television. Generally older people watch television than listen to the radio. Since television exist, radio is more often heard outside the home, for example on the way in the car, or while doing something. Watching television is usually done with a full focus, while listening to the radio can be done while doing other work. Because their position pressed by television, radio is now has more selective audience. Nowadays, most radio only serve certain circles, such as teenage music fans. This was disclosed by William L.Rivers, Jay W.Jensen and Theodore Peterson in their book, The Mass Media and Modern Society. (1993)

Television, apart as a news source also has a social function.For social contacts, it can be a references to daily life, to please ourself, take off the boredom and so on. Television channel in Indonesia, more generally provide information in the form of entertainment for the audience. Events on Indonesian television, especially private television channel, dominated by entertainment programs such as soap operas or infotainment. Moreover, at the present time, the Soap operas in Indonesia were more lead to negative things, has violence and pornography elements, as well as excessive delusion.

Television is a mass media that cater to the general public also has its advantages and disadvantages. According Khasali (2002) in carrying out its functions, the television has some advantages and disadvantages. There are some pros and cons of television Some of the advantages of television include:
1. Because of its audio-visual, viewers can be helped by the presence of the image. Therefore, everyone must have the same picture, theres no different image of the program .

2. Can watch the events in distant places without having to go to such places. This can be enjoyed in a live broadcast sporting events or music concerts. No need to go to England to watch the match between Manchester City against Manchester United. Simply sit back in front of the television to watch the match.

3. Can enjoy a variety of entertainment shows for free. No need to go to the movie theater to watch the film quality.

4. The information presented is up to date, all recent events can be watched on television.

5. The number of channels in the television makes everyone can watch their own favorite program (Morissan, 2008: 56-58)

Some dissadvantage of television which are (Morissan, 2008: 60):

1. Limited by the duration of the program and the length of visualization.

2. Cannot be heard passing by.

3. The possibility of program with violence, crime, and sex without censoring more. It can have bad influence, especially for children and adolescents.

4. As the electronic media, the message is fleeting.

5. The News that delivered areless profound (Morissan, 2008: 60).

The first research done by Gerbner in 1960 together with colleagues at the 
Annenberg School for Communication that aims to understand what is the real world thatv are imagined and perceived by television viewers. The tradition of media influence in the long term and televison; s indirect effects became its study in this research.

The argument originally was, "television has become an important member of the family, members that talk most often" (Severin and Tankard, 2001: 268). In the Cultural Indicators Project research there are five assumptions that Gerbner and colleagues studied:

1. Television essentially and fundamentally different from other forms of mass media. Televisions can be found in almost every household. Television does not require literacy as the media of newspapers, magazines and books. Television free of charge, while attractive because of the combination of image and sound.

2. Television became "the central cultural arm" of American society, as a source of entertainment and information offerings. Television has become an important member of the family, which is the most often to talk and telling.

3. Someone; perception as of television led to specific attitudes and opinions about the facts of life. Because most television stations have same audience targets, and depending on the kind of repetition and program (drama).

4. The main function of television is to the media of socialization and enculturation through the content impressions (news, drama, advertising) so that acceptance of the television could be a ritual viewer / sharing experiences rather than simply as a ransmissional view.

5. Observation, measurement, and contribution of television to the cultural is relatively small, but the impact was significant. According to this theory the television becomes a tool where the major media audiences learn about the society and culture in the environment, so the perception that built in audience minds about the society and culture is determined by the television.

The barriers from generation to generation are literacy and mobilitasteratasi with the presence of television. Television has become a common source especially for socialization and everyday information (mostly in the form of entertainment). Repeat patterns of the messages and the impression television are produced forming the mainstream of general symbolic environmental.

Garbner called this process as cultivation, because television is believed to act as a homogenizeragen in $t$ in culture. For Gerbner, compared to other mass media, television has gained such a significant place in our daily lives that dominate our "symbolic environment", by replacing its message of the reality of the personal experiences and how to of knowing the world (McQuail, 2011: 254).

Cultivation, in the meaning of the word means to plant, so in the meaning of the word cultivation theory can be interpreted as the theories that focus on value investment process. Cultivation Theory is one theory that can be used to explain the impact of the media for the mass. So, we can 
say that the cultivation research conducted by Gerbner more emphasis on "impact". The basic assumption in this theory is that continuous media exposure will provide an overview and influence on the perception of viewers. That is, as long as the viewers making contact with television they will learn about the world, they will change their perception, learn to behave and respect people.

Research cultivation stressed that the mass media as an agent of socialization and investigate whether the television audience believe what is presented by television than what they actually see. Gerbner and friends saw that movie drama presented on television have little influence but is very important in changing attitudes, beliefs, views the audience related to social environment.

Gerbner did a research about the impact of television using survey methods of analysis, where the sample population are men and women who are distinguished by age adults, children, and adolescents. Gerbner also uses data that most people in United State watch television in 7 hours a day.

This data is used to divide the respondents into two groups based on the time they watch television every day, a group of heavy television viewers or addict viewer and light viewers or casual viewer. At first this study is more focused on the study of television and the audience of violence themes, but along with the development of this theory is also used in social problems other than the theme of violence.

Theory Cultivation basically states that the heavy viewers build the belief that "the world was frightening." This is due to their belief of what they see on television, which tend to be a lot of presenting the violence, is what they believe occurs also in everyday life.

In this case, Gerbner stated that television is a dominant thing that can affect the modern society. The force comes from the ability of television through various symbols to provide various images that look real and important as a daily life. Television is able to influence the audience, so what is displayed on the screen is seen as a real-life, daily life. Reality that appear in the media is seen as an objective reality.

Based on the background that has been described, the formula of the problem in this research is; How the influence of sexual abuse of children cases on television toward the attitude of parents in the Stabat, Langkat

The purpose of this study is: to get a response toward the television coverage on cases of sexual abuse of children, and to know the effect of sexual abuse against children cases on television toward the attitudes of parents to keep and anticipate the cases so it does not happen to their children.

\section{RESEARCH METHODS}

The method used in this study is correlational method, it is a method which seeks to explain a problem or a more specifically indication between two different objects. This study methods aims to discover whether or not there is a relationship, and if so, how tight the relationship and how mean the relationship. Based on the things above, this study aims to determine how big the influence of reporting sexual abuse towards parental anxiety. The method used is to retrieve data through a questionnaire distributed to the respondents. 
This research location was conducted in Stabat, Langkat Sumatra Utara. Stabat is also the administrative capital of Langkat. Stabat is one sub-district in Langkat. Stabat is also the capital city of Langkat. Subdistrict with area $90.64 \mathrm{Km} 2$ is inhabited 83223 inhabitants (Langkat.go.id) The results of observations of researchers parents who are housewives in the district Stabat in Langkat is heavy television viewers. This allows the housewives get television media exposure is greater than other mass media.

The population in this study is housewives in the Perdaaian and Karang Rejo Village. Locations preferences by assuming the housewives in this region are quite cooperative, with 873 housewives. (Source: Monograph Kec. Stabat Langkat, 2015) .Researcher using purposive technique sampling. Sampling Criteria in this study were housewives in Stabat who have schoolage children thatare between the ages of 617 years old. The Sampling using 10\% of the total population technique and obtained 87 respondents.

\section{RESULTS}

The results showed respondents said news message content, accuracy and timeliness of news about cases of sexual harassment is good. Moreover the respondents believed the news that aired according by the fact that exist and provoke positive effect and to give the benefit for society. News about cases of sexual abuse againts children on television also may cause concern for the parents, which in turn raises awareness and concern for the parents that make effective communication between parents and children.

The results of hypothesis testing using the formula Spearman Rho showed Relations
Characteristics of respondents Variable and Attitude of Parents Variable ( $\mathrm{Y}$ ) has a low linear and positive relationship between two variables but not significant. Relations between News sexual abuse againts children on television Variable (X) and Parents Attitude Variable (Y) has a very strong and positive linear relationship between the two variables and the results also show no significant.

Based on the research results, it can be seen the influence of sexual abuse against children news cases on television toward the attitude of the parents in Stabat. Its discovered Spearman correlation (Rho) is 0.872 . Based on Guidford scale, the results of 0.872 indicates a very strong and definite linear relationship between two variables but not significant.

\section{CLOSING}

Interpersonal communication between parents and children can inflict the anticipation of sexual abuse for children both for girls and boys. For girls, it can be a defense for themselves to not become a victim of crime, whereas for boys, it can fortify themselves in order to behave positively.

\section{REFERENCES}

Aubrey, Fisher B. (2005). Teori- Teori Komunikasi. Rosdakarya Bandung,.

Birowo, Antonius M. (2004). Metode Penelitian Komunikasi: Teori dan Aplikasi. Gitanyali. Yogyakarta.

Bungin, Burhan. (2001). Metodologi Penelitian Sosial: Format- Format Kuantitatif dan Kuantitatif. Surabaya. Airlangga University Press. 
Bungin, Burhan. (2011). Metodologi Penelitian Kuantitatif. Jakarta; Kencana.

Creswell, JW. (1998). Qualitative inquiry and research design: Choosing among five traditions: Sage Publications, Inc.. California.

Defleur, M.L. \&S.j. Ball-Rokeach. (1989). Theoris of Mass Communication. fifth edition, Longman, new York \& London.

Devito, Joseph A. 1997. Komunikasi Antar manusia, Kuliah Dasar. Edisi Kelima. Jakarta: Profesional Books.

Hansen, Anders, Simon. (1998). Cottle. Mass Communication Reseach Metods Houndmills: Macmillan Press. New York

Muhammad, Arni. (2000). Komunikasi Organisasi. Jakarta: Bumi Aksara

Mulyana, Dedy. (2001). Nuansa- Nuansa Komunikasi: Meneropong Politikdan Budaya Komunikasi Masyarakat Kontemporer. Bandung: PT. Remaja Rosdakarya.

Newton Lawrence. (1997). Social Research Methode Qualitative and Quantitative Approach. Third Edition. Allyne and Bacon. Boston.

Usman, Husnaini \& Purnomo Stiady Akbar.2009. Metode Penelitian Sosial. Jakarta: Bumi Aksara

Warner, J Se verin \& James W Tankard, (2005). Teori Komunikasi. Prenada Media. Jakarta.

Walgito, Bimo. (2007). Psikologi Kelompok. Yogyakarta: Penerbit Andi.

Wahyudi. (2011). Televisi sebagai Media Komunikasi Massa, Jakarta, Media Karya 